\title{
ARTICLE
}

\section{A BRIEF GUIDE TO ONLINE TEACHING}

\author{
Margaret Ryznar* \\ TABLE OF CONTENTS
}

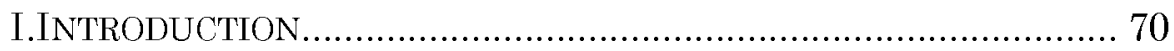

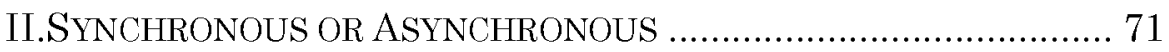

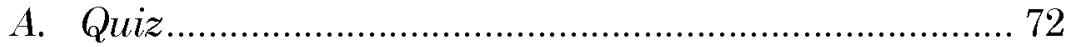

B. Explanation of Quiz ............................................. 74

1. Future Use of the Online Course.......................... 74

2. Lead Time............................................................ 75

3. Preparation Time........................................... 75

4. Size of Class ...................................................... 76

5. Type of Class ................................................ 76

6. Replicating the Classroom .................................. 77

7. Structure ...................................................... 77

8. Flexibility ...................................................... 77

9. Writing Skills ............................................... 78

10. Technology ............................................... 79

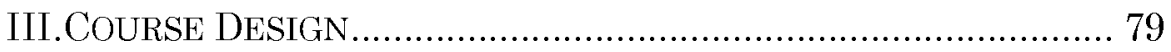

A. Synchronous Online Courses .................................... 81

1. Content Delivery ............................................ 81

2. Student Engagement......................................... 82

B. Asynchronous Online Courses ................................. 82

1. Content Delivery ............................................ 83

2. Student Engagement..................................... 84

IV.NEW ROLES FOR ONLINE PROFESSORS................................... 84

A. Content Creator ...................................................... 85

* Professor of Law, Indiana University Robert H. McKinney School of Law. 
V.CONCLUSION 86

APPENDIX A: QUESTIONS FOR TECHNOLOGY DEPARTMENT. 87

\section{INTRODUCTION}

Online teaching became commonplace during the coronavirus pandemic, and may be here to stay. ${ }^{1}$ Since then, much literature on online law teaching has arisen. ${ }^{2}$ This Article adds to this literature by providing a brief step-by-step guide to online teaching.

Part II of this Article therefore begins by examining the threshold question-whether an online course should be synchronous or asynchronous - and offers a quiz to help determine which format works best for each professor and course. Part III then discusses how professors can deliver content and engage students in both synchronous and asynchronous online courses. Finally, this Article highlights the roles of content creator and curator in online teaching.

1. See, e.g., John Villasenor, Online College Classes Are Here to Stay. What Does that Mean for Higher Education?, BROOKINGS (June 1, 2020), https://www.brookings.edu/blog/techtank/2020/06/01/online-college-classes-are-here-to-stay-what-does-thatmean-for-higher-education/; James DeVaney, Gideon Shimshon, Matthew Rascoff, \& Jeff Maggioncalda, Higher Ed Needs a Long-Term Plan for Virtual Learning, HARV. BUS. REV. (May 5, 2020), https:/hbr.org/2020/05/higher-ed-needs-a-long-term-plan-for-virtual-learning; Karen Sloan, ABA Legal Ed Council Votes to Expand Emergency Powers Amid the Coronavirus, LAW.COM (May 18, 2020, 12:30 PM) https://www.law.com/2020/05/18/aba-legal-ed-council-votes-to-expand-emergency-powers-amid-the-coronavirus/?slre-

turn=20210128215257 (explaining that, in response to the pandemic, the American Bar Association (ABA) gave law schools waivers on online education limits for the 2020-2021 academic year, allowing them to move some or all of their programming online).

2. For example, Miami Law Review, Saint Louis University Law Journal, Syracuse Law Review, and the Journal of Legal Education devoted entire issues to online teaching in 2020-2021. See, e.g., Nina A. Kohn, Online Learning and the Future of Legal Education: Symposium Introduction, 70 SYRACUSE L. REV. 1 (2020). Some literature on online teaching predated the pandemic. For example, Indiana Law Review published a symposium in 2018 hosted by Indiana University McKinney School of Law. Andrew Klein \& Max Huffman, Upward! Higher: How a Law School Faculty Stays Ahead of the Curve: Introduction, 51 IND. L. REV. 415 (2018). A 2018 review of the websites of the top 100 hundred law schools revealed that at least 30 of them were offering online courses as part of their law school curriculum. Research assistant memo on file with author. In 2018, the ABA, the regulator of law schools in the United States, increased the number of permissible online course to one-third of the credit hours required for the juris doctor law degree. How Online Learning is Revolutionizing Legal Education: A Discussion with Ken Randall of iLaw, ABOVE THE L. (Nov. 26, 2019, 4:16 PM), https://abovethelaw.com/2019/11/how-online-learning-is-revolutionizing-legal-education-a-discussion-with-ken-randall-of-ilaw/. 


\section{SYNCHRONOUS OR ASYNCHRONOUS}

The threshold decision for a professor embarking on online teaching is whether to teach synchronously or asynchronously. These two formats offer professors different ways to teach their courses online.

In an asynchronous online course, teaching is done in a timedelayed fashion through an online learning management system that students access at their convenience, with lessons organized by modules containing prerecorded lectures by the professor, readings, supplemental videos, and student assessment activities that often receive faculty feedback. " $[\mathrm{I}] \mathrm{n}$ the asynchronous classroom, instruction is typically self-paced with professors and students interacting - to the extent they interact—sequentially and with delay." 4

Synchronous online courses are done live in real-time, but through conferencing technology such as Zoom. ${ }^{5}$ Synchronous online teaching is similar to traditional classroom teaching because it is a real-time meeting of the professor and students, except on a technology platform instead of in a physical classroom. "So long as the professor... and students simultaneously can see one and hear everyone in the virtual classroom, the experience of teaching and learning will generally mirror the experience of teaching and learning in a residential classroom." ${ }^{6}$ Most professors adopted this approach to online teaching during the COVID19 pandemic because they were confronted with an emergency and lacked the time to build an asynchronous online course in advance. $^{7}$

To summarize, "[s]ynchronous means real-time and asynchronous means time-shifted." 8 Another notable difference is the technology on which each type of online teaching relies-synchronous

3. Kohn, supra note 2, at 9 . A learning management system is software such as Canvas, Blackboard, and TWEN. Best Practice Recommendations of Distance Learning for Legal Education 2.0, WORK GRP. DISTANCE LEARNING FOR LEGAL EDUC. 44-45

(2015) https://lawprofessors.typepad.com/files/bestpracticerecommendationsfordistance learningforlegaleducation-2015.pdf.

4. Kohn, supra note 2 , at 9 .

5. ZOOM, https://zoom.us/ (last visited Feb. 28, 2021).

6. Kohn, supra note 2 , at 8 .

7. See, e.g., Jon Marcus, Will the Coronavirus Forever Alter the College Experience?, N.Y. TIMES (June 25, 2020), https://www.nytimes.com/2020/04/23/education/learning/coronavirus-online-education-college html?action $=$ click\&module=Well\&pgtype=Homepage\&section=Education (suggesting that most schools shifting to online teaching in the Spring used Zoom as the primary method to deliver courses).

8. Max Huffman, Online Learning Grows $U_{p}$-And Heads to Law School, 49 IND. L. REV. 57, 58 (2015). 
online courses use a conferencing platform, while asynchronous online courses use a learning management system. ${ }^{9}$ Finally, asynchronous online teaching requires more of a robust course build than synchronous online teaching.

Based only on these descriptions of synchronous and asynchronous online teaching, some professors may already find one format inherently preferable to the other. Indeed, each type of online teaching benefits from distinct approaches that appeal to different professors depending on their skill sets, course goals, and personal interests. Alternatively, administrators may decide on a uniform approach for all faculty, with some schools preferring synchronous online courses and others preferring asynchronous online courses for various reasons. For most professors, however, the threshold decision between synchronous and asynchronous online teaching requires weighing several different factors, considered next.

\section{A. Quiz}

While a professor may ultimately use elements of both formats in the same course, it is helpful to determine whether the bulk of the course will be asynchronous or synchronous. This is because "[t]he difference between live and asynchronous teaching might affect everything from course design, to faculty selection and development, to the regulation of law schools." ${ }^{10}$ In addition, the most effective teaching practices differ depending on each format. ${ }^{11}$ Finally, consistency helps meet student expectations for the course.

Take the following quiz to see whether synchronous or asynchronous online teaching works better for you and your course. Award 1 point for every "yes" you answer. An explanation of the quiz follows.

\footnotetext{
9. See, e.g., BLACKBOARD, https://www.blackboard.com (last visited Mar. 22, 2021).

10. Kohn, supra note 2 , at $9-10$.

11. See id.
} 


\begin{tabular}{|l|l|l|}
\hline & YES & NO \\
\hline $\begin{array}{l}\text { 1. Are you teaching this online course more than } \\
\text { once? }\end{array}$ & & \\
\hline $\begin{array}{l}\text { 2. Do you have significant lead time to prepare this } \\
\text { course (over 2 months)? }\end{array}$ & & \\
\hline $\begin{array}{l}\text { 3. Are you able and willing to devote significant } \\
\text { prep time to this course (over 200 hours)? }\end{array}$ & & \\
\hline 4. Is this a large-enrollment class? & & \\
\hline 5. Is this a lecture course? & & \\
\hline $\begin{array}{l}\text { 6. Are you willing to depart significantly from the } \\
\text { classroom teaching experience? }\end{array}$ & & \\
\hline 7. Do you want the course to be highly structured? & & \\
\hline $\begin{array}{l}\text { 8. Do you want the course to maximize flexibility } \\
\text { for you and your students? }\end{array}$ & & \\
\hline $\begin{array}{l}\text { 9. Do you want to emphasize writing skills in this } \\
\text { course? }\end{array}$ & & \\
\hline 10. Are you comfortable with technology? & & \\
\hline
\end{tabular}

TOTAL

Professors scoring 6 points or more on this quiz should consider creating an asynchronous online course because they will reap several benefits from this format. They can also include some synchronous elements to lighten the workload of creating a completely asynchronous online course, such as Zoom sessions covering some course content or discussions. ${ }^{12}$

Professors scoring 5 points or less should consider teaching online synchronously. The synchronous online course format would accomplish many of their course goals.

However, each professor may weigh the various questions in this quiz differently-perhaps only one of the questions is determinative. For example, a professor may not want to devote over 200 hours to building an asynchronous online course, leaving synchronous online teaching as the only option. To help professors reach a final decision on whether to teach online synchronously or asynchronously, a further explanation of these quiz questions follows next. 


\section{B. Explanation of Quiz}

This section explains why a majority of affirmative answers to the above quiz should lead to the consideration of the asynchronous online format, while a majority of negative answers should lead to the consideration of synchronous online teaching. These in-depth explanations may also persuade professors to select one format over the other.

1. Future Use of the Online Course. Using the same online course more than once favors asynchronous online teaching. This is because repeated use of the course recovers the significant upfront investment that an asynchronous online build requires.

The need to use an online course again may be likely as some experts see a prolonged period of risk for contracting COVID-19..$^{13}$ Even with a vaccine, it may require more than one academic year to bring the disease under control given vaccine distribution and variants of the virus. ${ }^{14}$

It is worth noting that even after returning to the classroom post-pandemic, professors can re-use much of their asynchronous online content. For example, they may assign asynchronous online content when cancelling class due to illness, travel, inclement weather, or university closures. They may also assign parts of their asynchronous online content to supplement their live courses, or flip the classroom to reserve in-person meetings for active learning. ${ }^{15}$ The American Bar Association (ABA) currently allows up to one-third of a law course to be online before classifying it as an online course subject to credit hour limits. ${ }^{16}$ Thus, an investment in an asynchronous online class may have post-pandemic benefits.

13. "Although their forecasts and timelines vary, modellers agree on two things: COVID-19 is here to stay, and the future depends on a lot of unknowns, including whether people develop lasting immunity to the virus, whether seasonality affects its spread, andperhaps most importantly - the choices made by governments and individuals." Megan Scudellari, How the Pandemic Might Play Out in 2021 and Beyond, NATURE (Aug. 5, 2020), https://www.nature.com/articles/d41586-020-02278-5.

14. Ewen Callaway, Fast-Spreading COVID Variant Can Elude Immune Responses, NATURE (Jan. 21, 2021), https://www.nature.com/articles/d41586-021-00121-z.

15. Much has been written about flipping the classroom. See, e.g., Perry Binder, Flipping A Law Class Session: Creating Effective Online Content and Real World In-Class Team Modules, 17 AtLANTiC L.J. 34 (2015); William R. Slomanson, Blended Learning: A Flipped Classroom Experiment, 64 J. LEGAL EDUC. 93 (2014).

16. Memorandum from Maureen A. O'Rourke, Council Chair, Am. Bar Ass'n Section of Legal Educ. \& Admissions to the Bar, \& Barry A. Currier, Managing Dir. of Accreditation \& Legal Educ., Am. Bar Ass'n, to Interested Persons \& Entities (Feb. 22, 2018), 
2. Lead Time. An asynchronous online course cannot be built quickly. ${ }^{17}$ Several professors have estimated that a 3-credit asynchronous online course can take between 200 and 300 hours to build. ${ }^{18}$ While faculty can continue building the course as the semester progresses, to guarantee a high-quality course in its first run, the bulk of the work should be done before the semester begins given the amount of work it requires.

For this reason, administrators should give professors significant lead time before teaching an asynchronous online course, at least as much as for a new subject. Without sufficient lead time to build an asynchronous online course, professors should consider running an online course only synchronously, which can be prepared over the course of the teaching semester due to its easier transition from classroom teaching.

3. Preparation Time. Even if the professor has significant lead time before teaching an online course, the professor may decide against devoting so much time to building an online course for various reasons. In such a case, the professor should consider the synchronous online teaching method, which facilitates an easier transition from classroom teaching than the asynchronous method.

A professor's previous experience teaching the course in a traditional classroom may reduce the preparation time for building an online version, especially when it comes to an asynchronous online course. This is because the professor already has some course materials and lecture notes, which can create the basis for course modules and lecture videos. The professor with previous classroom teaching experience of the course also understands the arc of the course and knows where students may have trouble with the material, which both help in building an online course by providing a proven blueprint for the course.

https://www.americanbar.org/content/dam/aba/administrative/legal_education_and_admissions_to_the_bar/council_reports_and_resolutions/20180222_notice_and_comment.authcheckdam.pdf.

17. "With online courses, preparation is probably even more important than with traditional classroom teaching and the requirement for lead time is even greater. Plan your goals well in advance." Leslie Larkin Cooney, More Pedagogic Techniques: Online Exercises \& Integrating Skills into Different Kinds of Courses, 2009 TRANSACTIONS: TENN. J. Bus. L. 389, 391 (2009).

18. Yvonne M. Dutton \& Seema Mohapatra, COVD-19 and Law Teaching: Guidance on Developing an Asynchronous Online Course for Law Students, ST. LOUIS U. L.J. (forthcoming 2021). This has been the author's experience, as well. 
4. Size of Class. Synchronous online classes are not easy to teach with a large course enrollment. ${ }^{19}$ For example, Zoom does not show more than a certain number of students at once, requiring scrolling through several screens. In a large course, some students may prefer to shut off their cameras, prompting the question of whether professors should require students to leave their cameras on to see if they are learning and engaging with the course material. ${ }^{20}$

For these reasons, small courses lend themselves better to synchronous online class sessions. If a course is relatively large, the professor may want to consider running it as an asynchronous online course, which has the added benefit of the learning management system's ability to keep track of student progress and attendance.

5. Type of Class. A lecture-heavy course lends itself to asynchronous teaching because online lectures are best when they are pre-planned and short. This is because viewers have limited attention spans, and short lecture videos force professors to better organize, focus, and highlight the course material. ${ }^{21}$ Additionally, the recorded lecture videos in asynchronous online courses allow students to develop positive study habits, such as pausing, rewinding, and re-watching lectures as well as taking notes from them. Recorded lecture videos also allow students to pace themselves better to ensure that they understand the course material, giving them more time to formulate questions and answers. In contrast, seminar classes light on lectures lend themselves to the synchronous online format because back-andforth live discussions among fewer students can occur on Zoom just as in the classroom.

19. Jacqueline D. Lipton, Distance Legal Education: Lessons from the *Virtual* Classroom, 60 IDEA: L. ReV. Franklin PierCe Center For Intell. Prop. 71, 85 (2020) ("[S]ynchronous learning may not work particularly well with large online classes. Even sophisticated video-conferencing software doesn't scale up particularly well to large classes if a degree of interactivity is desired.").

20. See, e.g., Tabitha Moses, 5 Reasons to Let Students Keep Their Cameras Off During Zoom Classes, The Conversation (Aug. 12, 2020), https://theconversation.com/5-reasons-to-let-students-keep-their-cameras-off-during-zoom-classes-144111.

21. See, e.g., Philip Guo, Optimal Video Length for Student Engagement, EDX BLOG (Nov. 13, 2013), https://blog.edx.org/optimal-video-length-student-engagement ("The optimal video length is 6 minutes or shorter - students watched most of the way through these short videos. . . The take-home message for instructors is that, to maximize student engagement, they should work with instructional designers and video producers to break up their lectures into small, bite-sized pieces."). 
6. Replicating the Classroom. Professors wanting to replicate the traditional classroom should consider synchronous online teaching because it is done live and in real-time. Meanwhile, asynchronous online teaching differs from classroom teaching because the entire course is prepared in advance and runs in a time-delayed fashion in a learning management system, allowing professors and students to work when they wish instead of performing at a set time and place.

7. Structure. Professors who prefer highly controlled or structured learning environments might like asynchronous online teaching, which is completely pre-built and runs according to a strict plan. Meanwhile, professors who enjoy the spontaneous element of live teaching might prefer synchronous online teaching, which is done live and in-real time, albeit through conferencing technology.

8. Flexibility. Without live class meetings, asynchronous online courses maximize flexibility along many more measures than synchronous online courses. In particular, asynchronous online courses offer schedule flexibility so that students can complete course work late at night and on weekends to accommodate other commitments, the flexibility to do the course work on students' own time, the flexibility to go at their own pace, the geographic flexibility of not needing to commute to school, the flexibility to do the coursework during the times that they feel they are at peak performance, and the flexibility in the amount of time allotted to course assignments.

Synchronous online courses offer only geographic flexibility, but do not have the time flexibility of asynchronous online courses due to live class meetings. ${ }^{22}$ In a synchronous online course, everyone meets on conferencing technology at an appointed time, so schools need to schedule synchronous classes into the curriculum timetable to minimize overlap with other courses. To the extent that such courses overlap, students may not be able to take required and popular courses. Synchronous online courses may also be difficult for students given other household members' schedules and burdened internet connections at peak times. Different time zones may pose an additional challenge if students are in their home states. Recording synchronous classes, such as in Zoom, can help alleviate some of these challenges by allowing students to watch the recordings on their own time after the class meeting, 
but this may encroach on the privacy of the students being recorded and may make keeping track of student attendance and participation more difficult.

In terms of equity and accessibility, asynchronous online courses perform better than their synchronous counterparts do. Asynchronous online courses improve accessibility for students without technology or internet access because they can do the course at the library or a friend's or relative's home on a mutually convenient schedule. If multiple people in a household must share a computer, students can take turns working on their coursework without having to be in the course at a particular time. Finally, in an asynchronous online course, students do not need to appear before a web camera, sparing them concern about their socioeconomic environment. Asynchronous online courses thus offer important advantages for professors to consider before selecting an online format.

9. Writing Skills. Course learning outcomes have received widespread attention recently. For example, the ABA has released guidance on learning outcomes and assessment programs in recent years. ${ }^{23}$

Learning outcomes can be helpful in determining which online format to use. Specifically, a synchronous online course is more likely to emphasize speaking skills given that the professor may call on students in live-time to respond to questions, similarly to a traditional classroom course. Live discussions between the students and professor are also common in synchronous online courses. Meanwhile, asynchronous online courses may instead require students to do writing exercises to engage with the material throughout the semester, such as short-answer quizzes and discussion boards. ${ }^{24}$ The professor often has many opportunities in an online course management learning system to comment on written submissions to further strengthen student writing skills with feedback.

23. See, e.g., A.B.A., Managing Director's Guidance Memo: Standards 301, 302, 314 and 315 (June 2015), https://www.americanbar.org/content/dam/aba/administrative/legal_education_and_admissions_to_the_bar/governancedocuments/2015_learning_outcomes_guidance.authcheckdam.pdf.

24. See Cooney, supra note 17, at 390 ("In our experience, students' drafting and editing is more thoughtful because they are working outside of class on their own time, and because they know their work-everything that they write-will be online for their classmates to see."). 
10. Technology. Being comfortable with the learning management system is essential to asynchronous online teaching. Years before COVID-19, many schools adopted a learning management system that facilitates online teaching, such as Canvas. Older ones include Blackboard and TWEN. Such learning management systems typically require a university license to use, but more basic versions may be available for no cost. $^{25}$ Professors may find it useful to discuss their options with their school's technology department. ${ }^{26}$

It is invaluable to use an institutional learning management platform. Such a platform is standardized and has an online community beyond the university that allows the professor to search for answers to almost any question online. ${ }^{27}$

Professors can also build an asynchronous online course through a series of web pages or even blog posts, using private platforms such as Weebly or WordPress. However, there may be concerns related to student privacy and online security when using such private systems. Certain university policies may therefore prohibit the use of such platforms.

Any video conference platform can work for synchronous online teaching, and requires less technological adaptation than building an asynchronous online course in a learning management system. The most popular video conference platform adopted during COVID-19 was Zoom. ${ }^{28}$ Professors can also use non-video platforms such as instant messenger, online chat-room technology, phone conferences, and audio conferences to teach their online synchronous online course, but they miss the important visual element that video provides.

\section{COURSE DESIGN}

After selecting an online teaching format of synchronous or asynchronous, professors need to turn their attention to content

\footnotetext{
25. See, e.g., Canvas, InSTRUCtURE, https://www.instructure.com/canvas/try-canvas (last visited Feb. 28, 2021).

26. See infra Appendix A for questions to ask the technology department.

27. See, e.g., Home: Canvas Community, InstruCTURE, https://community.canvaslms.com/ (last visited Feb. 28, 2021).

28. See, e.g., Lauren Aratani, 'Zoom University': Is College Worth the Cost Without the In-Person Experience?, THE GUARDIAN (Oct. 6, 2020), https://www.theguardian.com/world/2020/oct/06/zoom-university-college-cost-students-in-person-experience (noting the term "Zoom University" for universities relying heavily on Zoom delivery synchronously).
} 
delivery and student engagement in their preferred online formats. These are the two hallmark characteristics of online teaching.

All teaching necessarily involves content delivery, but it has heightened importance in online teaching for several reasons. First, the ABA, the regulator of law schools in the United States, requires a certain amount of online content per credit hour. ${ }^{29}$ Second, online content is necessary to substitute for the live discussions and Socratic method that take up in-person class time, but are not as available or easy online..$^{30}$ Finally, content helps students learn the material. ${ }^{31}$

Online teaching efforts should also focus on student engagement, the other important element in online teaching. When asked about the worst possible online courses, people conjure up either a series of three-hour pre-recorded lectures in an asynchronous online course or Skype sessions in a synchronous online course..$^{32}$ Indeed, in the move online due to COVID-19, many classes were criticized for failing to engage students. ${ }^{33}$ This is also the problem with Massive Open Online Courses (MOOC's). Although many of them use best practices for online teaching, such as short video lectures, they necessarily lack engagement from the professor due to their sheer number of students. Their high failure rate

29. Huffman, supra note 8 , at 68 . "To award a credit hour, a course must offer instruction equal to fifty minutes of instruction weekly for fifteen weeks, equal to 750 minutes of instruction. Synchronous online courses, which meet at regularly scheduled times for set class periods, can calculate their minutes of instruction similarly to live classes. Asynchronous online courses are not amenable to a similarly simple calculation." Id.

30. Id. at 61 ("The case method and Socratic dialogue is less than perfectly amenable to teaching using online methods. One-on-one verbal discourse between the professor and student, observed by other students who imagine themselves in the hot-seat, is difficult to conduct at a distance. Synchronous teaching using audio-conference or chat-room technology makes Socratic dialog possible, but stilted.").

31. See generally Kenneth R. Swift, The Seven Principles for Good Practice in [Asynchronous Online] Legal Education, 44 MitChELl HAMLINE L. REv. 105, 118 (2018) (noting how people learn).

32. "Our image of online teaching is pretty grim. We tend to imagine online professors recording lengthy, mind-numbingly unstimulating lectures via video or voice over slides with instructional goals no more ambitious than the hope that the lectures magically pour knowledge into the brains of students. We imagine the students isolated in their homes, dressed in their pajamas, lacking connection or inspiration." Michael Hunter Schwartz, Towards A Modality-less Model for Excellence in Law School Teaching, 70 SYRACUSE L. REV. 115, 116 (2020).

33. Anna Esaki-Smith, For College Faculty And Students, A 'Socially Sensitive' Alternative To Zoom, FORBES (Dec. 9, 2020, 8:01 AM), https://www.forbes.com/sites/annaesakismith/2020/12/09/for-college-faculty-and-students-a-socially-sensitive-alternativeto-zoom $/$ ? sh=303b338f69fb. "While subject matter expertise is essential to student learning ..., creating an atmosphere where students feel respected, cared about, and supported may be even more important." Schwartz, supra note 32 , at 136. 
may partly result from this lack of student engagement. ${ }^{34}$ Thus, student engagement is especially important in online teaching.

The methods of achieving content delivery and student engagement differ in synchronous and asynchronous online courses, although some of the tools are the same. These are considered next.

\section{A. Synchronous Online Courses}

Professors will recognize many of the synchronous online teaching tools as the same ones used in classroom teaching. This is because synchronous teaching is live teaching, except through conferencing technology.

1. Content Delivery. Since synchronous online courses meet live on an electronic platform, such as Zoom, the content delivery will mostly be done verbally by the professor, either through a lecture or discussion. Synchronous classes can even feature Socratic dialogue, which is the traditional method of delivering content to students in law school. ${ }^{35}$

Verbal communication can be supplemented by sharing the professor's computer screen with students on video conferencing platforms such as Zoom. For example, the professor's computer screen can display a PowerPoint presentation or other multimedia, such as an informative video, which students view together with the professor.

Notably, screens cause fatigue for some. ${ }^{36}$ To ease this, professors should exhibit high energy and enthusiasm levels during synchronous class meetings, and perhaps include a mid-point break. Furthermore, professors should be structured in their online synchronous class time, explaining the outline and structure for the particular class, and the intended learning outcomes. Professors can share their computer screen with the class outline and learning outcomes written out. Professors should be especially careful not to roam or saunter through the course material during a synchronous class meeting, and class preparation should focus on delivering organized course content. Course handouts or

34. Doug Lederman, Why MOOCs Didn't Work, in 3 Data Points, Inside Higher ED (Jan. 16, 2019), https://www.insidehighered.com/digital-learning/article/2019/01/16/studyoffers-data-show-moocs-didnt-achieve-their-goals (free MOOCs at edX averaged less than $10 \%$ completion rates in 2016 ).

35. Huffman, supra note 8, at 59.

36. Liz Fosslien \& Mollie West Duffy, How to Combat Zoom Fatigue, HaRv. Bus. Rev. (Apr. 29, 2020), https://hbr.org/2020/04/how-to-combat-zoom-fatigue. 
posted PowerPoints are also helpful by allowing students to focus on the class session without worrying about taking detailed notes.

2. Student Engagement. Like in the traditional classroom, the professor can call on students during the synchronous online class to engage them and check whether they are comprehending the material. If student cameras are on, professors can also observe their students to see if students are learning during class and adjust their teaching accordingly.

There are several methods to facilitate student engagement and participation on video conferencing platforms, such as putting students on participation panels or calling on them in a predictable pattern, such as in alphabetical order. These tools put students on notice of when they should be particularly prepared to speak in front of the online class, while the remainder of the class can comfortably focus on the course content. Forming break-out groups in Zoom may also make students more comfortable to speak given the smaller group. ${ }^{37}$ In addition, the professor can interact with students beyond discussions, such as quizzing or polling students and then commenting on the results.

Many of these methods are already familiar to professors given their use in the traditional classroom. Thus, content delivery in synchronous online courses does not require a significant departure from live teaching. This differs from asynchronous online courses, considered next.

\section{B. Asynchronous Online Courses}

Asynchronous online classes are markedly different from live classes. $^{38}$ In some ways, they are similar to authoring a textbook because they require planning and presenting course material from start to finish in the course website on the school's learning management system. From the student's perspective, it may be similar to a directed or independent reading. Throughout this endeavor, like in synchronous online courses, professors should consider content delivery and student engagement.

\footnotetext{
37. See Cass R. Sunstein, Self-Silencing and Online Learning, J. LEGAL EDUC. (forthcoming) (manuscript at 2), https://papers.ssrn.com/sol3/papers.cfm?abstract_id=3663208 (noting that the problem of "[s]elf-silencing is everywhere" when students believe that their views are out of step with those of their peers on topics such as politics, religion, gender, and race). Self-silencing seems less likely to occur in smaller groups of students.

38. Kohn, supra note 2 , at 9 .
} 
1. Content Delivery. The main content delivery methods for asynchronous online courses are pre-recorded lectures, other videos, messages, and written materials arranged in the school's learning management system. ${ }^{39}$ The course content is divided into modules, with each module containing some combination of video lectures, written text, supplemental videos, and assessments, such as quizzes or discussion boards. ${ }^{40}$ "In terms of developing actual online content, it's worth noting that ten to twenty-minute lectures seem to be today's 'sweet spot' for length, often followed by brief, interactive comprehension questions or discussion questions, and ultimately more detailed assessment exercises." 41

To facilitate content delivery, professors might try writing scripts for their lectures, setting up a teleprompter or taping their printed-out script in front of their computer screen, and recording themselves lecturing through a screen recorder program licensed by the university, such as Kaltura, Zoom, or Adobe. ${ }^{42}$ Private but inexpensive programs that may have better editing features include Camtasia and Screencast-O-Matic. Professors may also decide to run a PowerPoint in a screen recording program while narrating the lecture in a split-screen video. PowerPoint even has an audio recording feature within it. To access this feature, with the PowerPoint presentation open, professors should click "Record Slide Show" on the Slide Show tab. ${ }^{43}$

Course design is particularly important when it comes to organizing asynchronous online content. Professors should consider Steve Jobs's view of utility as a driver of design, which propelled Apple products into mainstream use. ${ }^{44}$ "Courses are effectively designed if the teaching, assessments, reading and other assignments, and learning objectives are congruent with each other, and if the delivery of instruction is efficient, effective, and appealing." 45 Indeed, "[s]ome best practices for online teaching that those students are looking for include an organized structure and content flow, engaging lectures, materials that connect the content to the

39. See, e.g., Yvonne M. Dutton et al., Assessing Online Learning in Law Schools: Students Say Online Classes Deliver, 96 DENV. L. REV. 493, 513 (2019).

40. Id.

41. Lipton, supra note 19 , at 95 .

42. Teleprompters are available online. See, e.g., EASYPROMPTER, https://www.easyprompter.com/ (last visited Feb. 28, 2021).

43. See MiCROSOFT SUPPORT, https:/support.microsoft.com/en-us/office/record-apresentation-2570dff5-f81c-40bc-b404-e04e95ffab33 (last visited Feb. 28, 2021).

44. "Steve Jobs perfected design thinking at Apple. . . Jobs' products were aesthetically pleasing and delightful because of their utility." Peter Lee \& Madhavi Sunder, The Law of Look and Feel, 90 S. CAL. L. REV. 529, 575 (2017).

45. Schwartz, supra note 32 , at 132 
'real world,' and assignments that allow students to check their understanding of the material and that are practical for when they graduate law school." 46 It helps to secure the assistance of the University's computer design experts, if such resources exist for online teaching on campus.

2. Student Engagement. In asynchronous online classes, student engagement must double as assessment given that the professor cannot see or hear signals of the students' learning while teaching. Thus, professors must create assessments, such as discussion boards and quizzes, which can include essay and multiple choice questions. Learning management systems offer templates for such assessments and "easily track how often a student logs in, contributes to class discussions, engages in interactive quizzes, and so on." 47 Private tools are also available, such as Google Forms for quizzes. Professors can also turn to CALI quizzes and materials provided by their casebook authors. ${ }^{48}$ Professors may offer these assessments as ungraded formative or graded summative assignments. ${ }^{49}$ Both are effective in ensuring students stay on track with the material and engage with it. ${ }^{50}$

In an asynchronous online course, it is especially important to motivate students to continue with the course. Feedback by the professor on assessments helps intrinsically motivate the students, which can be more powerful than extrinsic motivation, such as grades. ${ }^{51}$ The school's learning management system often offers easy ways to comment on student work, either individually or as a class. Professors can also send announcements or emails on a regular basis to connect with students.

\section{NEW ROLES FOR ONLINE PROFESSORS}

Given the nature of online teaching, regardless of whether synchronous or asynchronous, professors become content curators and content creators. These roles, new to some professors, are important to content delivery and student engagement.

46. Yvonne M. Dutton, Margaret Ryznar \& Kayleigh Long, Assessing Online Learning in Law Schools: Students Say Online Classes Deliver, 96 DENV. L. REV. 493, 531 (2019).

47. Lipton, supra note 19 , at 89.

48. See CALI, https://www.cali.org/lesson (last visited Feb. 26, 2020).

49. See Olympia Duhart, "It's Not For A Grade": The Rewards and Risks of Low-Risk Assessment in the High-Stakes Law School Classroom, 7 ELON L. REV. 491 (2015).

50. Margaret Ryznar, Assessing Law Students, 51 IND. L. REV. 447, 449 (2018) (describing how summative and formative assessments provide grades or feedback to students and faculty on course performance).

51. Margaret Ryznar \& Yvonne M. Dutton, Lighting A Fire: The Power of Intrinsic Motivation in Online Teaching, 70 SYRACUSE L. REV. 73, 82, 101 (2020). 


\section{A. Content Creator}

Content creation is abundant in the age of technology. Many people now even earn their livelihoods by creating new content for blogs, YouTube, and other online platforms. ${ }^{52}$ Younger generations often consume and create content themselves. ${ }^{53}$ This shapes them as students when they arrive at law school. ${ }^{54}$

Professors are placed into this role of content creator when online teaching. They must create lecture videos, PowerPoints, polls, quizzes, and other content for student consumption. Creating one's own content is important because it allows better tailoring to the course than using other people's existing materials, such as CALI lessons. ${ }^{55}$ It also creates a more personalized course and preserves the professor's discretion in selecting course materials.

\section{B. Content Curator}

A curator builds collections. Curation usually includes the selection, categorization, assembly, commentary, and presentation of the most relevant materials on a particular topic.

A professor teaching online must build up a collection of materials in each online lesson, including personally created, original content as well as third-party content made available for teaching by the fair use doctrine. ${ }^{56}$ The professor must curate materials

52. For example, "[m]any of these content creators on YouTube use video games as a medium, add their commentary to entertain, and earn ad revenue to make a profit." Nicholas Ribaudo, YouTube, Video Games, and Fair Use: Nintendo's Copyright Infringement Battle with YouTube's 'Let's Plays" and Its Potential Chilling Effects, 6 BERKELEY J. ENT. \& SPORTS L. 114, 115 (2017). See also Jeff Rose, How Much Do YouTubers Really Make?, FORBES (Mar. 21, 2019, 8:15 AM), https://www.forbes.com/sites/jrose/2019/03/21/howmuch-do-youtubers-really-make/?sh=4f8c8d0d7d2b.

53. "Indeed, whether using social media sites to participate in discussions about culture, trends, current events and ideas, voting online on how a given advertiser's commercial should end, playing complex virtual video games with other players free of the traditional boundaries of time and space, building or adding to websites, customizing their Nike sneakers or creating blogs, this generational group 'flock[s] to brands who allow them to take ownership of ideas.' That inclination renders this demographic and the one that follows particularly likely to grasp, practice, apply and enjoy conceptual teaching and learning." Paula A. Franzese, Law Teaching for the Conceptual Age, 44 SETON HALL L. REV. 967, 981$82(2014)$

54. "Millennials' generational learning style is shaped by their pre-law school, academic experiences." Renee Nicole Allen \& Alicia R. Jackson, Contemporary Teaching Strategies: Effectively Engaging Millennials Across the Curriculum, 95 U. DET. MERCY L. REV. 1, 6 (2017).

55. See supra note 48.

56. "Fair use gives ... the right to use the copyrighted work of others 'for purposes such as ... teaching (including multiple copies for classroom use), scholarship, or research." David S. Olson, First Amendment Based Copyright Misuse, 52 WM. \& MARY L. REV. 537, 558 (2010) (quoting 17 U.S.C. 107 (2006)). 
that supplement or highlight the lesson, whether a video, audio, or text clip. These must then be imported or embedded in online modules or Zoom sessions in a seamless and interactive way. Ideally, the material is arranged in an inviting and engaging format.

\section{CONCLUSION}

Synchronous and asynchronous online courses differ from each other, but both need to guarantee content delivery and student engagement, which are the hallmarks of online teaching. Professors may use both synchronous and asynchronous elements in their courses-for example, a synchronous online course might have at-home quizzes through the school's learning management system, while an asynchronous online course may have Zoom office hours or social meetings. Alternatively, a professor can run a flipped classroom, with synchronous meetings reserved for discussions or problem sets. ${ }^{57}$ Nonetheless, the bulk of an online course typically will be either synchronous or asynchronous.

This Article aimed to facilitate the decision on online teaching format, whether it be synchronous and asynchronous. Once professors select their preferred format, they can offer students a high-quality online experience, both during the pandemic and beyond, by focusing on content delivery and student engagement.

57. See supra note 15 and accompanying text. 


\section{APPENDIX A: QUESTIONS FOR TECHNOLOGY DEPARTMENT}

1. What conferencing technology does the school use for synchronous classes? (For example, Zoom, Skype, Google Meet, etc.)

2. What learning management system does the school use for asynchronous classes? (For example, Canvas, Blackboard, TWEN, etc.)

3 . What screen recorder does the school license for prerecording lecture videos from one's office? (For example, Kaltura, Zoom, Adobe, etc.)

4. Is there a budget to purchase non-licensed programs and software? (For example, Camtasia, Screencast-O-Matic, Snagit, etc.)

5. Is there a budget to buy online teaching technology such as a webcam?

6. Does the University have a professional recording studio or media production space in which faculty may pre-record lectures?

7. Does the University have resources to help with online course design? (For example, Teaching \& Learning Center, Office of Online Education, eLearning Design and Services, etc.) 